\title{
GAMBARAN HIGIENE PERORANGAN BERDASARKAN PERSEPSI POLA ASUH ANAK DI UPTD KAMPUNG ANAK NEGERI KOTA SURABAYA
}

\author{
Riana Bintang Rozaaqi*, Sri Widati** \\ * Departemen Promosi Kesehatan dan Ilmu Perilaku, Fakultas Kesehatan Masyarakat Universitas Airlangga \\ ** Ikatan Ahli Kesehatan Masyarakat Indonesia \\ Kampus C Mulyorejo Surabaya, 60115 \\ Email: rbintangr17@gmail.com
}

\begin{abstract}
Lack care of childs personal hygiene can cause some health problems such as diarrhea, worms, scabies, and others. Parenting contribute on the personal hygiene behaviour. The aim of this study was to described childs personal hygiene based on parenting perception of children in UPTD Kampung Anak Negeri Surabaya. This study was a descriptive cross sectional study with quantitative approach. The sample was 30 foster children with determining the sample by random sampling. Data were taking with questionnaires and interview. Instrument used in this study was questionnaires and interview guideline. Data analysis were conducted with descriptive analysis. The results was most of the foster children were 12-16 years old. Most of the foster children was in the road more than 7 months. The majority of foster children was schoolless. Most of the foster children was entered the UPTD because singing in the road. Most of the foster children had a good personal hygiene. Most of the foster children had democratic perception on parenting. The conclusion of this study is foster children that have otoriter, democratic, as well as permissive perception on parenting have good perception on personal hygiene.
\end{abstract}

Keywords: personal hygiene, parenting, foster children

\begin{abstract}
ABSTRAK
Perawatan higiene perorangan anak yang kurang dapat menimbulkan berbagai masalah kesehatan seperti diare, cacingan, scabies, dan lain-lain. Pola asuh memberikan kontribusi dalam perilaku higiene perorangan. Tujuan penelitian ini adalah untuk menggambarkan higiene perorangan anak berdasarkan persepsi pola asuh anak di UPTD Kampung Anak Negeri Kota Surabaya. Penelitian ini merupakan penelitian deskriptif cross sectional dengan pendekatan kuantitatif. Responden penelitian sebanyak 30 anak asuh dengan penentuan sampel menggunakan cara random sampling. Pengambilan data dilakukan dengan kuesioner dan wawancara. Instrumen yang digunakan adalah kuesioner dan panduan wawancara. Analisis data dilakukan secara deskriptif. Hasil dari penelitian ini adalah sebagian besar anak asuh berusia 12-16 tahun. Sebagian besar anak asuh berada di jalan lebih dari 7 bulan. Mayoritas anak asuh tidak bersekolah. Sebagian besar anak asuh masuk UPTD karena mengamen. Mayoritas anak asuh memiliki personal hygiene baik. Mayoritas anak asuh memiliki persepsi pola asuh demokratis. Kesimpulan dari penelitian ini adalah anak asuh dengan persepsi pola asuh otoriter, demokratis maupun permisif memiliki persepsi higiene perorangan yang baik.
\end{abstract}

Kata kunci: higiene perorangan, pola asuh, anak asuh

\section{PENDAHULUAN}

Sehat menurut WHO (1948) adalah keadaan sejahtera dari fisik, mental, dan sosial serta terhindar dari penyakit dan kecacatan. Menurut Undang-undang Nomor 36 tahun 2009 tentang Kesehatan, yang dimaksud dengan sehat adalah kondisi sejahtera baik dalam segi fisik, mental, sosial dan spiritual serta berkesempatan untuk hidup secara produktif.

Higiene perorangan merupakan salah satu contoh masalah kesehatan yang 
dihadapi Indonesia. Berdasarkan data Riskesdas tahun 2013, sebanyak 82,6\% masyarakat usia $\geq 10$ tahun telah melakukan BAB dengan benar. Cuci tangan dengan benar hanya dilakukan oleh $47 \%$ dari jumlah penduduk Indonesia. Masalah higiene perorangan maupun kebersihan lingkungan memiliki peranan penting dalam tumbuh kembang anak. Higiene perorangan yang kurang, memungkinkan seseorang berisiko untuk terserang penyakit kulit dan saluran pencernaan seperti diare, cacingan, scabies, karies gigi, dan lain-lain (Soetjiningsih, 1995).

Provinsi Jawa Timur merupakan salah satu wilayah di Indonesia dengan penduduk mencapai 37.47 juta jiwa (BPS Jawa Timur, 2010). Salah satu permasalahan kesehatan di jawa Timur adalah diare. Menurut data Ditjen PP dan PL Kemenkes RI tahun 2010, menyatakan bahwa Jawa Timur terjadi KLB (kejadian luar biasa) diare tertinggi, yaitu sebanyak 1.181 orang penderita dan 12 orang meninggal (Profil Kesehatan Indonesia, 2012).

Diare dapat disebabkan oleh rendahnya higiene perorangan. Higiene perorangan merupakan upaya untuk menjaga kesehatan yang dilakukan oleh individu maupun kelompok dengan cara menjaga higiene perorangan dan mengendalikan keadaan lingkungan sekitarnya (Depkes RI, 2006). Menurut Andarmoyo dan Isro'in (2012) higiene perorangan ada 6 yaitu, higiene kulit, higiene kuku, kaki, dan tangan, higiene rambut, higiene mulut dan gigi, higiene mata serta higiene telinga dan hidung.

Masyarakat Indonesia yang rentan untuk dapat melakukan higiene perorangan adalah kelompok anak jalanan maupun anak terlantar. Menteri Sosial menyebutkan bahwa anak terlantar adalah individu yang tidak terpenuhi kebutuhan dasarnya dengan wajar secara jasmani, rohani maupun sosial oleh orang tuanya karena beberapa alasan. Anak jalanan adalah individu dengan rentang usia 6 tahun sampai dengan 18 tahun yang menghabiskan sebagian besar waktunya untuk hidup di jalan atau tempat umum. Waktu yang dihabiskan oleh anak untuk hidup di jalan adalah lebih dari 4 jam dalam satu hari (Direktorat Kesejahteraan Anak, Keluarga, dan Lanjut Usia, 2001).

Persoalan kemiskinan dan kesehatan merupakan hal sulit yang dihadapi oleh anak jalanan dan anak terlantar. Keterbatasan keadaan dan sulitnya akses menyebabkan kualitas jaminan perawatan, kesehatan dan kehidupan yang layak masih terbilang kurang (Raffaelli dan Koller, 2005). Upaya negara dalam mengentaskan masalah ini adalah dengan membentuk Lembaga Kesejahteraan Sosial Anak (LKSA) (Menteri Sosial, 2010). Pembentukan LKSA ini bertujuan untuk memenuhi kebutuhan dari anak bermasalah sosial. Lembaga kesejahteraan sosial anak ini ada yang dikelola oleh pemerintah dan ada juga yang dikelola masyarakat. Lembaga kesejahteraan sosial anak yang dikelola oleh pemerintah salah satunya adalah UPTD Kampung anak Negeri Kota Surabaya. Sedangkan lembaga kesejahteraan sosial anak yang dikelola oleh masyarakat biasanya disebut dengan panti asuhan, atau berbagai lembaga kesejahteraan sosial lain. Meskipun lembaga ini dapat memenuhi kebutuhan anak terhadap pendidikan, pangan dan tempat tinggal, pada kenyataannya sebagian besar lembaga tersebut tidak banyak memberikan pengasuhan yang memadai bagi anak (Kementerian Sosial, Save Children, UNICEF, 2007).

Seringkali pengasuh menggolongkan anak ke dalam golongan tertentu tanpa melihat konteksnya (Rothbart dan Bates, 1998; Wachs, 2000). Pengasuhan yang diberikan di suatu lembaga disamaratakan, anak diperlakukan sama. Padahal untuk mencapai suatu tujuan dari pengasuhan diperlukan cara asuh yang sesuai dengan kondisi. Seperti yang diungkapkan oleh Sanson dan Rothbart (1995) bahwa tidak ada satu cara asuh yang terbaik. Pengasuhan yang diberikan disesuaikan dengan kondisi anak tertentu. 
Baumrind (1956, dalam Bigner, 1979, Santrock, 1994) mengemukakan empat pola asuh, yaitu pola asuh otoriter, demokratis, permisif, dan penolakan. Setiap pola asuh memiliki ciri tertentu. Pola asuh otoriter memiliki ciri kendali dipegang penuh oleh pengasuh, anak dituntut untuk mematuhi peraturan yang dibuat pengasuh, dan tidak ada komunikasi antara orang tua dan anak. Pola asuh demokratis memiliki ciri pengasuh memberikan kesempatan kepada anak untuk menentukan pilihannya sendiri. Namun pengasuh juga memberikan bimbingan dan pengarahan serta adanya komunikasi antara anak dan pengasuh. Pola asuh permisif memiliki ciri pengasuh membolehkan anak melakukan sesuatu yang diinginkan, tidak adanya pengawasan dan bimbingan yang diberikan, dan keakraban antara anak dan pengasuh kurang. Sedangkan ciri dari pola asuh penolakan adalah pengasuh tidak memberikan perhatian kepada kebutuhan anak, jarang memiliki harapan terkait masa depan anak, dan ketidakpedulian pengasuh terhadap kebutuhan anak.

Pola pengasuhan yang diberikan pengasuh kepada anak diterima dengan persepsi yang berbeda-beda tiap anak. Persepsi adalah suatu proses pengorganisasian dan penginterpretasian terhadap stimulus yang diterima oleh sesorang sehingga menjadi sesuatu yang bermakna bagi dirinya (Walgito: 2004). Respons yang diterima dan diwujudkan dalam bentuk tindakan setiap individu berbeda. Hal ini menyebabkan perilaku tiap individu berbeda. Perbedaan perilaku tiap individu dapat memengaruhi kesehatan individu itu sendiri. Studi awal yang dilakukan pada 6 september 2016, didapatkan hasil bahwa masalah kesehatan yang sering terjadi adalah terkait higiene perorangan seperti kulit gatal, sakit gigi, sakit mata, diare, dan lain-lain. Oleh karena itu, tujuan penelitian ini adalah untuk menggambarkan higiene perorangan berdasarkan persepsi pola asuh anak di UPTD Kampung Anak Negeri Kota Surabaya.

\section{METODE}

Metode penelitian yang digunakan adalah pendekatan kuantitatif. Jenis penelitian adalah penelitian deskriptif cross sectional. Sampel dari penelitian adalah sebanyak 30 anak asuh UPTD Kampung Anak Negeri Kota Surabaya. Penentuan sampel dengan cara random sampling. Teknik pengumpulan data adalah dengan kuesioner dan wawancara. Data yang dihasilkan berupa data kuantitatif dari hasil kuesioner dan data kualitatif dari hasil wawancara yang digunakan untuk menguatkan data kuesioner. Sedangkan instrumen yang digunakan adalah kuesioner dan panduan wawancara. Analisis data dilakukan secara deskriptif.

\section{HASIL}

Berdasarkan data hasil penelitian dapat diketahui bahwa karakteristik anak asuh berdasarkan usia, tingkat pendidikan, lama berada di jalan, dan latar belakang masuk UPTD Kampung Anak Negeri Kota Surabaya adalah sebagai berikut:

Berdasarkan Tabel 1. dapat diketahui bahwa mayoritas anak asuh adalah berumur 12-16 tahun. Mayoritas anak asuh adalah tidak sedang menempuh pendidikan atau tidak bersekolah. Mayoritas anak asuh berada di jalan lebih dari 7 bulan. Sebagian besar anak asuh masuk UPTD Kampung Anak Negeri karena mengamen.

Berdasarkan data yang diperoleh dari penelitian, persepsi higiene kulit, rambut, mata, kuku, kaki dan tangan anak asuh di UPTD Kampung Anak Negeri didapatkan hasil sebagai berikut:

Berdasarkan Tabel 2. dapat diketahui bahwa mayoritas anak asuh memiliki persepsi sudah menjaga higiene kulit, rambut dan mata dengan baik.

Persepsi dalam menjaga higiene kulit adalah mandi 2 kali sehari, mandi menggunakan sabun, dan mencuci seprei 2 minggu sekali. Hasil wawancara terkait higiene kulit didapatkan kesimpulan bahwa masih adanya anak asuh yang meminjam peralatan mandi milik teman. Hal ini seperti yang diungkapkan oleh AJ: 
Tabel 1. Distribusi Frekuensi Karakteristik Anak Asuh di UPTD Kampung Anak Negeri Kota Surabaya 2017

\begin{tabular}{|c|c|c|}
\hline $\begin{array}{c}\text { Karakteristik Anak } \\
\text { Asuh }\end{array}$ & Jumlah & $\begin{array}{l}\text { Persentase } \\
\text { (\%) }\end{array}$ \\
\hline \multicolumn{3}{|l|}{ Usia } \\
\hline$<11$ tahun & 7 & 23,3 \\
\hline 12-16 tahun & 13 & 43,3 \\
\hline$>17$ tahun & 10 & 33,3 \\
\hline Total & 30 & 100 \\
\hline \multicolumn{3}{|l|}{ Pendidikan } \\
\hline SD & 9 & 30 \\
\hline SMP & 1 & 3,3 \\
\hline SMA & 2 & 6,7 \\
\hline Tidak Sekolah & 18 & 60 \\
\hline Total & 30 & 100 \\
\hline \multicolumn{3}{|l|}{ Lama Berada di Jalan } \\
\hline $0-3$ bulan & 13 & 43,3 \\
\hline 4-6 bulan & 0 & 0 \\
\hline$>7$ bulan & 17 & 56,7 \\
\hline Total & 30 & 100 \\
\hline \multicolumn{3}{|l|}{ Alasan Masuk UPTD } \\
\hline Mengamen & 11 & 36,7 \\
\hline Anak Terlantar & 2 & 6,7 \\
\hline $\begin{array}{l}\text { Datang Sendiri ke } \\
\text { UPTD }\end{array}$ & 6 & 20 \\
\hline Diantar Keluarga & 6 & 20 \\
\hline Diantar Orang Lain & 5 & 16,7 \\
\hline Total & 30 & 100 \\
\hline
\end{tabular}

"gak punya handuk mbak, punyaku hilang. Yowes (ya sudah), mending pinjam punya teman ae (saja) daripada hilang terus. Kadang ya habis mandi gak pakai handuk." (AJ, 12 tahun).

Selain itu masih adanya anak asuh yang mengganti pakaian sehari sekali. Ketika di wawancara alasan jarang mengganti pakaian adalah tempat menjemur pakaian kurang luas. Sehingga ketika anak asuh akan mencuci dan cucian temannya belum kering maka anak asuh memilih untuk tidak mencuci. Hal ini seperti yang diungkapkan oleh JH:
Tabel 2. Distribusi Frekuensi Higiene Kulit, Rambut, Mata, Kuku, Kaki dan Tangan Anak Asuh di UPTD Kampung Anak Negeri Kota Surabaya 2017

\begin{tabular}{lcc}
\hline Higiene Kulit & Jumlah & Persentase (\%) \\
\hline Baik & 23 & 76,7 \\
Cukup & 7 & 23,3 \\
Kurang & 0 & 0 \\
\hline Total & 30 & 100 \\
\hline \multicolumn{1}{c}{ Higiene } & Jumlah & Persentase (\%) \\
\hline \multicolumn{1}{c}{ Rambut } & 20 & 66,7 \\
Baik & 5 & 16,7 \\
Cukup & 5 & 16,7 \\
Kurang & 30 & 100 \\
\hline Total & Jumlah & Persentase (\%) \\
\hline Higiene Mata & 8 & 66,7 \\
\hline Baik & 2 & 26,7 \\
Cukup & 30 & 6,7 \\
Kurang & 100 \\
\hline Total & 30 & 100 \\
\hline Higiene Kuku, & Jumlah & Persentase (\%) \\
\hline Kaki, Tangan & & 70,7 \\
Baik & 21 & 26,7 \\
Cukup & 8 & 3,3 \\
Kurang & 1 & \\
\hline Total & & \\
\hline
\end{tabular}

"males mbak, wong (orang) anak-anak kalau nyuci itu mesthi (selalu) gak cepatcepat diangkat kalau sudah kering. Aku males nyuci mbak, nek (kalau) jemuran penuh. Soale nanti anak-anak marah kalau tak (saya) pindah bajunya." (JH, 15 tahun).

Tabel 2. menunjukkan bahwa persepsi dalam menjaga higiene rambut adalah menggunakan sampo saat keramas dan keramas 2 kali dalam seminggu. Hasil wawancara dalam menjaga higiene rambut dapat disimpulkan bahwa anak asuh keramas hampir setiap hari menggunakan sampo. Hal ini seperti yang diungkapkan oleh LU: 
"loh, tertib mbak. Kalau keramas ya pakai sampo to mbak. Sampone (samponya) ambil di ruang Pembina. Aku hampir setiap hari keramas." (LU, 11 tahun).

Sedangkan persepsi dalam menjaga higiene mata berdasarkan Tabel 2. adalah membersihkan ujung mata dengan tisu atau tangan. Berdasarkan Tabel 2. mayoritas anak asuh memiliki persepsi bahwa sudah menjaga higiene kuku, kaki dan tangan. Persepsi menjaga higiene kuku, kaki, dan tangan yang dilakukan anak asuh diantaranya adalah memotong kuku seminggu sekali menggunakan alat pemotong kuku, mencuci kaki dan tangan ketika hendak tidur, dan mencuci tangan sebelum makan. Kesimpulan dari hasil wawancara yang dilakukan menyebutkan bahwa anak asuh memotong kuku dua minggu sekali atau 1 minggu sekali. Hal ini seperti yang diungkapkan oleh ES terkait higiene kuku, yaitu:

"Ya biasanya setiap hari jumat mbak, sama pembina dilihat kukunya disuruh motong kukunya sebelum jumatan. Pakai cathut kuku (pemotong kuku). Kalau ndak pakai itu ya pakai gunting biasanya. Tapi, kalau tidak disuruh motong, ya ndak motong kuku mbak." (ES, 11 tahun).

Terkait higiene kaki, dari hasil wawancara dapat disimpulkan bahwa masih adanya anak asuh yang jarang menggunakan sandal untuk kesehariannya. Hal ini dikuatkan oleh pernyataan HS, yaitu:

"Gak punya sandal mbak, mesthi (selalu) hilang kalau punya sandal. Kadang yo (ya) pinjem temen kalau buat mandi atau wudhu." (HS, 13 tahun).

Sedangkan dari wawancara terhadap higiene tangan dapat disimpulkan bahwa masih ada anak asuh yang tidak mencuci tangan sebelum makan. Hal ini seperti yang diungkapkan oleh RZ yaitu:
"Ya itu mbak, kalau nggak disuruh pak tentara ya gak cuci tangan mbak. Kan cuci tangannya sudah pas wudhu itu." (RZ, 11 tahun).

Tabel 3. menunjukkan bahwa mayoritas anak asuh berpersepsi memiliki higiene mulut dan gigi yang baik. Persepsi menjaga higiene mulut dan gigi diantaranya adalah menggosok gigi dengan pasta gigi dan sikat gigi, menggosok gigi 2 kali dalam sehari dan mengganti sikat gigi secara rutin. Wawancara yang telah dilakukan mendapatkan kesimpulan bahwa masih ada beberapa anak asuh yang malas menggosok gigi dengan rutin karena tidak terbiasa. Hal ini seperti yang diungkapkan oleh $\mathrm{JH}$, yaitu:

"males gosok gigi mbak. Dhisik (dulu) kan pas (waktu) di jalan biasa ga gosok gigi. Biasa ga mandi 2 hari. Jadi kalau disuruh gosok gigi yo (ya) emoh (gamau). Gak enak rasane (rasanya) mbak." (JH, 15 tahun).

Sedangkan untuk persepsi menjaga higiene telinga dan hidung pada Tabel 3 . menunjukkan cukup. Persepsi anak asuh dalam menjaga higiene telinga dan hidung yaitu membersihkan kotoran telinga dan

Tabel 3 Distribusi Frekuensi Higiene Mulut dan Gigi dan Telinga dan Hidung Anak Asuh di UPTD Kampung Anak Negeri Kota Surabaya 2017

\begin{tabular}{lcc}
\hline $\begin{array}{c}\text { Higiene Mulut } \\
\text { dan Gigi }\end{array}$ & Jumlah & Persentase (\%) \\
\hline Baik & 20 & 66,7 \\
Cukup & 8 & 26,7 \\
Kurang & 2 & 6,7 \\
\hline Total & 30 & 100 \\
\hline Higiene Telinga & Jumlah & Persentase (\%) \\
dan Hidung & & 43,3 \\
Baik & 13 & 53,3 \\
Cukup & 16 & 3,3 \\
Kurang & 1 & 100 \\
\hline Total & 30 &
\end{tabular}


hidung dengan tangan secara rutin. Hasil wawancara dapat disimpulkan bahwa anak asuh membersihkan telinga 2 minggu sekali dengan menggunakan cotton buds. Namun ada beberapa anak asuh yang menggunakan tangan untuk membersihkan telinga. Anak asuh membersihkan telinga dengan tangan karena tidak terbiasa menggunakan cotton buds. Hal ini seperti yang diungkapkan oleh DD yaitu:

"gak mbak. Gak pernah dibersihno (dibersihkan) pembina kalau telinga. Bersihno (bersihkan) sendiri lah mbak. Kadang ya setiap minggu, kadang ya 2 minggu. Gamau pakai cotton buds karena rasane (rasanya) geli-geli gimana gitu mbak." (DD, 13 tahun).

Tabel 4. Distribusi Frekuensi Anak Asuh Berdasarkan Persepsi Higiene Perorangan di UPTD Kampung Anak Negeri Kota Surabaya 2017

\begin{tabular}{|c|c|c|}
\hline $\begin{array}{l}\text { Higiene } \\
\text { Perorangan }\end{array}$ & Jumlah & Persentase $(\%)$ \\
\hline Baik & 22 & 73,3 \\
\hline Cukup & 8 & 26,7 \\
\hline Kurang & 0 & 0 \\
\hline Total & 30 & 100 \\
\hline
\end{tabular}

Tabel 4. menunjukkan bahwa mayoritas anak asuh memiliki persepsi higiene perorangan yang baik. Persepsi yang dimiliki oleh anak asuh dapat dipengaruhi oleh faktor lingkungan berupa pola pengasuhan yang diterima dan faktor dalam diri sendiri.

Berdasarkan data yang diperoleh dari penelitian, persepsi pola asuh anak adalah sebagai berikut:

Berdasarkan Tabel 5. mayoritas anak asuh memiliki persepsi pola asuh demokratis. Pola asuh demokratis memiliki ciri pelibatan anak dalam pengambilan keputusan. Selain itu anak diberi kesempatan untuk memilih yang terbaik untuk dirinya namun tetap dalam bimbingan pengasuh. Berdasarkan hasil wawancara dapat disimpulkan bahwa
Tabel 5. Distribusi Frekuensi Anak Asuh Berdasarkan Persepsi Pola Asuh di UPTD Kampung Anak Negeri Kota Surabaya 2017

\begin{tabular}{lcc}
\hline $\begin{array}{c}\text { Persepsi Pola } \\
\text { Asuh }\end{array}$ & Jumlah & Persentase (\%) \\
\hline Otoriter & 9 & 30 \\
Demokratis & 13 & 43,3 \\
Permisif & 8 & 26,7 \\
Penolakan & 0 & 0 \\
\hline Total & 30 & 100 \\
\hline
\end{tabular}

adanya perbedaan antara persepsi pola asuh yang diterima anak asuh yang berumur $>$ 15 tahun dan $<15$ tahun. Anak asuh yang berusia $>15$ tahun memiliki persepsi bahwa mereka selalu diberi kesempatan oleh pengasuh dalam menentukan semua hal. Seperti yang diungkapkan oleh HN yaitu:

"gak pernah mbak kalau dituntut gini gitu. Ya dijarno (dibiarkan) aja. Pengen apa ya dibebaskan. Kadang ya malah ngajak ngobrol enaknya kalau gini gitu gimana. Soale wes gede (soalnya sudah besar) mbak. Masak iya dimarahi terus, kan wes ngerti (kan sudah mengerti)." (HN, 19 tahun).

Sedangkan anak asuh yang berusia $<15$ tahun berpersepsi bahwa mereka sering diminta untuk mengikuti keinginan dari pengasuh. Hal ini seperti yang diungkapkan oleh HS yaitu:

"mesthi (selalu) mbak diseneni (dimarahi) kalau tidak mau melakukan yang dikatakan bapake (bapaknya). Daripada dimarahi yo(ya) nurut ae (saja) mbak." (HS, 13 tahun).

Tabel 6. menunjukkan bahwa persepsi pola asuh otoriter, demokratis maupun permisif cenderung memiliki persepsi higiene perorangan yang baik. Ciri khas pola asuh otoriter adalah menuntut anak untuk mematuhi semua aturan yang dibuat. Pola asuh otoriter cenderung memberikan perintah 
Tabel 6. Tabulasi Silang antara Higiene Perorangan dengan Persepsi Pola Asuh Anak asuh di UPTD Kampung Anak Negeri Kota Surabaya 2017

\begin{tabular}{|c|c|c|c|c|c|c|c|c|}
\hline \multirow{3}{*}{ Persepsi Pola Asuh } & \multicolumn{6}{|c|}{ Higiene Perorangan } & \multirow{2}{*}{\multicolumn{2}{|c|}{$\begin{array}{l}\text { TOTAL } \\
\text { Baik }\end{array}$}} \\
\hline & \multicolumn{2}{|c|}{ Baik } & \multicolumn{2}{|c|}{ Cukup } & \multicolumn{2}{|c|}{ Kurang } & & \\
\hline & $\mathrm{n}$ & $\%$ & $\mathbf{n}$ & $\%$ & $\mathbf{n}$ & $\%$ & $\mathbf{N}$ & $\%$ \\
\hline Otoriter & 7 & 77,8 & 2 & 22,2 & 0 & 0 & 9 & 100 \\
\hline Demokratis & 10 & 76,9 & 3 & 23,1 & 0 & 0 & 13 & 100 \\
\hline Permisif & 5 & 62,5 & 3 & 37,5 & 0 & 0 & 8 & 100 \\
\hline Rejecting & 0 & 0 & 0 & 0 & 0 & 0 & 0 & 100 \\
\hline
\end{tabular}

dan larangan kepada anak serta menuntut kedisiplinan. Hal ini memungkinkan anak asuh yang berpersepsi pola asuh otoriter memiliki persepsi higiene perorangan yang baik.

Ciri khas dari pola asuh demokratis adalah memberikan bimbingan dan wawasan namun tidak menuntut, menunjukkan hal yang baik dan buruk sehingga anak dapat menentukan sesuatu yang baik untuk dilakukan. Hal ini memungkinkan anak asuh untuk berpikir dan memutuskan untuk menjaga higiene perorangan dengan baik. Sedangkan ciri khas dari pola asuh permisif yaitu anak diperbolehkan melakukan sesuatu yang diinginkannya dan pengasuh mendidik dengan acuh tak acuh. Hal ini memungkinkan anak asuh untuk mandiri dan mencari hal yang benar sehingga dapat memilih untuk menjaga higiene perorangan dengan baik.

\section{PEMBAHASAN}

Menurut Departemen Kesehatan (2009), kategori umur yaitu masa balita (0-5 tahun), masa kanak-kanak (5-11 tahun), masa remaja awal (12-16 tahun), masa remaja akhir (17-25 tahun). Hal ini menunjukkan bahwa anak asuh termasuk dalam kategori remaja awal.

Berdasarkan hasil penelitian di UPTD Kampung Anak Negeri Kota Surabaya didapatkan hasil bahwa anak asuh tidak bersekolah. Hal ini karena anak asuh banyak yang putus sekolah. Putus sekolah yang dialami oleh anak asuh pada tingkat yang berbeda-beda. Ada yang putus sekolah pada tingkat sekolah dasar, sekolah menengah pertama maupun sekolah menengah atas. Sebagian besar anak asuh yang tidak bersekolah karena keadaan ekonomi. Pendidikan bagi setiap individu sangatlah penting. Pendidikan merupakan arahan yang dapat digunakan untuk menuntun hidup menuju kebahagiaan dan keselamatan bagi setiap manusia (Suwarno, 1988).

Alasan anak asuh masuk UPTD Kampung Anak Negeri sebagian besar karena mengamen. Anak asuh yang mengamen menghabiskan sebagian waktunya untuk berada di jalan. Mereka mengamen karena berbagai alasan. Ada yang awalnya kabur dari rumah lalu mengamen, ada yang membantu orang tua mencari uang untuk memenuhi kebutuhan hidup, ada yang ikutikutan teman dan ada juga yang mengamen karena keinginan sendiri.

Mereka yang sering berada di jalan karena mengamen, hingga akhirnya saat ada razia Satpol PP terjaring. Mereka yang terjaring razia Satpol PP kemudian diserahkan ke UPTD Kampung Anak Negeri Kota Surabaya. Namun ada beberapa anak asuh yang tidak langsung dimasukkan ke UPTD Kampung Anak Negeri, melainkan dimasukkan ke Liponsos Keputih terlebih dahulu sebelum dipindah ke UPTD Kampung Anak Negeri.

Hal ini karena sebagian besar anak asuh dari keluarga yang kurang mampu 
dan kurang harmonis. Akhirnya mereka memilih untuk lebih banyak menghabiskan waktu di jalan untuk bekerja atau sekedar bersenang-senang dengan temannya. Hal ini sesuai dengan penelitian yang dilakukan oleh Rahmadani (2013) bahwa hal yang menjadi faktor anak berada di jalan adalah karena ekonomi, ketidakharmonisan keluarga dan pengaruh teman.

Perilaku higiene perorangan dalam penelitian ini adalah upaya yang dilakukan oleh individu dalam memelihara higiene perorangan. Higiene perorangan ini meliputi higiene kulit, higiene kuku, kaki dan tangan, higiene rambut, higiene mulut dan gigi, higiene mata, serta higiene telinga dan hidung (Hidayat, 2008). Berdasarkan penelitian yang dilakukan di UPTD Kampung Anak Negeri Kota Surabaya diperoleh hasil bahwa sebagian besar anak asuh menjaga higiene kulit dengan baik. Sebagian besar anak asuh menjaga higiene kulit sesuai dengan yang diungkapkan oleh Siswanto (2010), yaitu mandi menggunakan sabun, air bersih dan rutin dilakukan dua kali dalam sehari. Namun, hasil wawancara menyebutkan bahwa masih adanya beberapa anak yang tidak menggunakan handuk setelah mandi dan mengganti pakaian sekali dalam sehari. Pakaian yang lembab akan menyebabkan timbulnya jamur dan bakteri yang kemudian dapat mengganggu kesehatan kulit seperti gatal-gatal. Hal ini sesuai dengan penelitian yang dilakukan oleh Sandriana et al . (2014) yang mengutarakan bahwa pakaian yang lembab dapat memicu tumbuhnya bakteri dan jamur.

Berdasarkan hasil penelitian sebagian besar anak asuh memiliki persepsi higiene rambut yang baik. Anak asuh telah menerapkan langkah menjaga higiene rambut sesuai dengan yang diungkapkan oleh Potter dan Perri (2005), yaitu keramas menggunakan sampo minimal 2 kali dalam seminggu.

Hasil wawancara yang telah dilakukan, didapatkan hasil bahwa sebagian besar anak asuh memiliki persepsi higiene mata yang baik. Langkah yang dilakukan anak asuh dalam menjaga higiene mata yaitu membersihkan mata menggunakan tisu dan/atau tangan. Pembersihan mata dengan menggunakan tangan bukan merupakan cara yang baik untuk dilakukan. Hal ini sesuai dengan yang diutarakan oleh Potter (2006) bahwa pembersihan mata dilakukan ketika mandi atau bisa menggunakan kain lap yang dilembapkan ke dalam air. Ketika pembersihan mata dilakukan dengan menggunakan tangan akan berisiko untuk terjadinya iritasi pada mata. Debu dan kotoran yang menempel pada tangan dapat masuk ke dalam mata apabila tidak memperhatikan higiene tangannya.

Menjaga higiene kuku, kaki, dan tangan sangatlah penting dilakukan. Kuman penyakit dapat masuk ke dalam tubuh melalui kuku, kaki dan tangan yang tidak bersih (Siswanto, 2010). Kuku yang panjang dan tidak terawat memudahkan telur cacing menempel di bawah kuku (Gandahusada, 2000).

Tangan merupakan bagian tubuh yang sensitif dan mudah menularkan penyakit. Suatu penyakit dengan mudah berpindah saat kita mengambil makanan dengan kondisi tangan atau tempat yang kotor (Al Fanjari, 1999). Masalah kesehatan yang dapat muncul akibat tidak menjaga higiene kuku dan tangan contohnya adalah diare (Budi, 2006). Hal ini sesuai dengan penelitian yang dilakukan oleh Rosyidah (2014) yang menyebutkan bahwa ada hubungan antara kejadian diare dengan kebiasaan cuci tangan. Tujuan mencuci tangan yaitu untuk membersihkan kotoran dan debu secara mekanis dari permukaan kulit dan mengurangi jumlah mikroorganisme (Tietjen, 2003). Mencuci tangan dengan menggunakan sabun terbukti dapat mengurangi kejadian dan penyebaran penyakit menular seperti diare, infeksi saluran pernapasan atas (ISPA) dan Flu Burung (Depkes, 2010). Selain itu, tidak mencuci tangan menggunakan sabun juga dapat menyebabkan kecacingan. Hal ini didukung oleh penelitian yang dilakukan 
Alemu et al . (2011) dan Awasthi et al . (2008) yang menyebutkan bahwa adanya hubungan bermakna antara mencuci tangan dengan sabun terhadap kejadian kecacingan pada anak.

Selain itu, kebiasaan tidak menggunakan sandal akan memungkinkan larva cacing tambang di tanah masuk menembus kulit kaki atau tangan. Larva ini berada di tanah karena tanah merupakan media tempat tumbuhnya cacing tambang dalam kelangsungan hidupnya (Depkes RI, 2007). Jika hal ini dibiarkan maka memungkinkan kejadian kecacingan pada anak asuh. Hal ini sesuai dengan penelitian yang dilakukan oleh Fitri et al . (2012) yang menyebutkan bahwa ada pengaruh bermakna penggunaan alas kaki dengan kejadian infeksi kecacingan. Selain itu, hal ini juga didukung oleh penelitian yang dilakukan Adikankwu et al . (2012) dan Ahmed et al . (2011) yang menyebutkan bahwa kebiasaan bermain di tanah tidak menggunakan alas kaki berisiko terinfeksi cacing yang ditularkan melalui tanah.

Berdasarkan hasil penelitian yang dilakukan didapatkan hasil bahwa masih ada anak asuh yang tidak membersihkan telinga dengan teratur dan tidak menggunakan alat pembersih telinga. Masih adanya anak asuh yang membersihkan telinga dengan menggunakan tangan. Hal ini tidak sesuai dengan yang diungkapkan oleh Hidayat (2008) bahwa membersihkan telinga hendaknya menggunakan alat yang bersih dan aman. Pemakaian alat yang tidak sesuai dapat merusak gendang telinga (Potter, 2006). Pemeliharaan higiene hidung yang dilakukan oleh anak asuh sebagian besar adalah menggunakan tangan. Hal ini tidak sesuai dengan yang diungkapkan oleh Samsunar (1978) bahwa dalam membersihkan hidung harus dengan cara mendenguskannya pelanpelan, bukan menggunakan tangan.

Faktor dalam diri sendiri bisa dipengaruhi oleh faktor pengetahuan individu. Pengetahuan dapat memengaruhi seseorang untuk melakukan suatu tindakan.
Hal ini seperti yang diungkapkan oleh Notoatmodjo (2003) bahwa pengetahuan merupakan aspek yang sangat penting untuk terbentuknya suatu perilaku dari individu. Hal ini sejalan dengan penelitian yang dilakukan oleh Nita (2014) tentang faktor yang berhubungan dengan perilaku higiene perorangan pada saat menstruasi di SMP Muhammadiyah 5 Yogyakarta, bahwa terdapat pengaruh yang signifikan faktor pengetahuan terhadap perilaku higiene perorangan pada siswi kelas VII di SMP Muhammadiyah 5 Yogyakarta.

Sedangkan, faktor lingkungan dari terbentuknya perilaku adalah pola asuh yang diterima. Pola asuh dapat memengaruhi perilaku anak asuh. Pendidikan pertama adalah dari pengasuhnya. Hal ini sejalan dengan penelitian yang dilakukan Dasilva (2012) yang menyebutkan bahwa pola pengasuhan memengaruhi status higiene perorangan. Penelitian lain yang mendukung adalah penelitian yang dilakukan Mardliyah et al . (2013) menyebutkan bahwa pola pengasuhan memengaruhi pemenuhan kebutuhan dasar higiene perorangan. Penelitian sebelumnya yang dilakukan oleh Naim (2016) menyebutkan bahwa ada hubungan kuat antara pola asuh orang tua dengan status higiene perorangan pada anak prasekolah di RA Al-Hidayah Dusun Pagotan Desa Keplaksari Peterongan Jombang sebesar 0,627.

Penerapan pola asuh yang berbeda akan memungkinkan perilaku anak yang berbeda pula tergantung dari pengasuhan yang diberikan. Pola asuh permisif memiliki ciri control pengasuh yang kurang, hukuman yang minimal, dan pengasuh tidak menetapkan aturan kepada anak untuk berperilaku (Turner, Chandler dan Heffer, 2009). Joshi dan Acharya (2013) menambahkan bahwa anak dengan pola asuh permisif memiliki kebebasan dalam melakukan sesuatu yang diinginkan tanpa persetujuan dari pengasuh. Pola asuh permisif dapat membentuk anak yang tidak bertanggung jawab, tidak menghargai orang 
lain, kontrol diri yang buruk, kurang mandiri, nakal dan kurang percaya diri (Wong et al ., 2008). Konsep diri ini terbentuk karena pola asuh ini memberikan kehangatan kepada anak, bersifat longgar, bimbingan yang diberikan kurang, memanjakan anak, dan keinginan anak dituruti. Sehingga hal ini memberikan kebebasan kepada anak. Pola asuh ini cenderung tidak memaksa dan memperingatkan anak apabila anak salah atau dalam bahaya. Namun, tidak semua pola asuh permisif membentuk konsep diri anak yang negatif. Penelitian yang dilakukan menunjukkan hasil bahwa persepsi pola asuh permisif dapat membentuk anak untuk berperilaku higiene perorangan yang baik.

Pola asuh otoriter cenderung memaksa kedisiplinan dan tuntutan yang tinggi kepada anak, menggunakan hukuman apabila anak melakukan salah dan tidak menuruti keinginan pengasuh, dan tidak memberikan kesempatan anak untuk menjelaskan kesalahan atau kegagalan yang dialami. Pola asuh otoriter ini akan membentuk anak menjadi penakut, pendiam, tertutup, tidak memiliki inisiatif, dan suka melawan. Hal ini dapat mengganggu pertumbuhan dan perkembangan anak secara psikologis untuk ke depannya. Namun, hal ini tidak berlaku dalam penelitian yang dilakukan. Anak dengan persepsi pola asuh otoriter memiliki perilaku higiene perorangan yang baik. Bahkan dibanding dengan pola asuh demokratis dan permisif, pola asuh ini lebih tinggi tingkat higiene perorangannya.

Sedangkan pola asuh demokratis merupakan pola asuh yang dalam penerapannya rasional. Pola asuh ini memiliki ciri penentuan peraturan dan disiplin selalu mempertimbangkan alasan yang dapat diterima, dipahami dan dimengerti oleh anak. Pengasuh memberikan pengarahan dan bimbingan kepada anak dengan penuh pengertian, dan dapat menciptakan keharmonisan dalam keluarga (Idris dan Jamal, 1992). Pola asuh demokratis menumbuhkan keyakinan dan kepercayaan diri pada anak sehingga anak menjadi mandiri. Anak belajar untuk bertanggung jawab, dapat mengontrol diri, memiliki hubungan baik dengan orang lain, dapat menghadapi tekanan, dan memiliki inovatif.

Pola asuh merupakan cara yang digunakan oleh pengasuh untuk mendorong anak mencapai tujuan yang diinginkan agar selaras dengan lingkungannya. Tujuan tersebut antara lain yaitu pengetahuan, nilai moral, dan acuan perilaku yang harus dimiliki oleh anak (Tridhonanto, 2014). Setiap anak memiliki persepsi pola asuh yang berbeda. Pola pengasuhan ini terdiri dari 4, yaitu pola asuh otoriter, demokratis, permisif, dan penolakan (Baumrind, 1965, dalam Bigner, 1979, Santrock, 1994). Pola asuh ini dapat memengaruhi sesorang dalam melakukan perilaku sehat. Penelitian yang dilakukan oleh Herlina (2013) menyebutkan bahwa adanya hubungan pola asuh keluarga dengan kemandirian anak dalam melakukan perawatan diri. Sedangkan analisis dari penelitian tersebut menyebutkan adanya perbedaan antara kemandirian diri anak dengan pola asuh demokratis, otoriter dan pola asuh permisif.

Berdasarkan hasil penelitian, didapatkan hasil bahwa persepsi pola asuh otoriter, demokratis, dan permisif memiliki persepsi higiene perorangan baik. Persepsi pola asuh otoriter terjadi karena berdasarkan hasil wawancara, anak asuh dengan usia $<15$ tahun merasa bahwa pengasuh menuntut dan memaksa untuk menuruti perintah. Hal ini memungkinkan anak untuk berperilaku higiene perorangan baik. Namun hal ini tidak sesuai dengan yang diungkapkan oleh Aisyah (2010) bahwa anak yang sering diperlakukan kasar dan dituntut maka akan memungkinkan anak tersebut memiliki sifat yang agresif dan pemarah. Anak yang pemarah dan lebih agresif memungkinkan untuk tidak mematuhi nasihat yang diutarakan oleh pengasuh dalam penerapan higiene perorangan. Hasil penelitian tidak sejalan dengan penelitian yang dilakukan oleh Mardliyah et al . (2013) yang menyebutkan 
bahwa penerapan pola asuh yang baik adalah pola asuh demokratis sehingga kualitas kebutuhan dasar higiene perorangan dapat terpenuhi dan dapat membentuk anak untuk mandiri. Penelitian tersebut didukung oleh Hidayat (2006) bahwa pola asuh demokratis membentuk konsep diri anak positif dalam berperilaku, sedangkan pola asuh otoriter dan permisif membentuk konsep diri anak yang negatif.

Pernyataan yang diungkapkan oleh Hidayat (2006) tidak sejalan dengan pernyataan yang diungkapkan oleh Riyadi (2009) dalam Lintang (2014) bahwa pola asuh permisif dapat memenuhi kebutuhan anak baik secara fisik maupun psikis. Penerapan pola asuh permisif merupakan salah satu cara yang diterapkan pengasuh sebagai bentuk rasa sayang dan cara mengajarkan anak untuk mandiri.

Pola asuh yang terima anak baik pola asuh otoriter, permisif, dan demokratis semua baik. Penerapan pola asuh pengasuhan disesuaikan dengan anak. Hal ini sesuai dengan yang diungkapkan oleh Sanson dan Rothbart (1995) bahwa tidak ada salah satu pola asuh yang terbaik melainkan penerapan pola asuh disesuaikan dengan tujuan yang ingin dicapai dan kondisi anak.

\section{SIMPULAN}

Higiene perorangan merupakan hal yang sangat penting. Perawatan higiene perorangan yang kurang akan menimbulkan berbagai masalah kesehatan. Perilaku higiene perorangan dipengaruhi oleh faktor lingkungan yaitu pola asuh yang diberikan. Persepsi pola asuh otoriter, demokratis maupun permisif memiliki persepsi higiene perorangan yang baik. Masih adanya anak asuh yang belum menerapkan higiene perorangan maka diperlukan pendekatan oleh pengasuh untuk mengetahui keadaan anak asuh. Pendekatan ini dilakukan pengasuh agar dapat menentukan pola asuh yang akan diterapkan untuk mewujudkan higiene perorangan anak yang lebih baik.

\section{DAFTAR PUSTAKA}

Adikankwu, O.R., Odikamnoro, O.O., Uhuo, A.C., dan Nwuzo, A.C., 2012. The Prevalence of Intestinal Nematode in School Children in Ebonyi Local Government Area, Ebonyi State, Nigeria. [e-journal] Continental J. Biomedical Science, Vol. 6. Tersedia di: $<$ http://www.scilit.net/article/10.5707/ cjbmsci.2012.6.1.13.17> [diakses pada tanggal 7 Agustus 2017].

Ahmed, A., Al-Mekhlafi, H.M., Choy, S.H., Ithoi, I., Al-Adhroey, A.H., Abdulsalam., A.M., dan Surin, J., 2011. The Burden of Moderate-to-Heavy Soil-Transmitted Helminth Infections Among Rural Malaysian Aborigines: An Urgent Need for An Integrated Control Programme. [e-journal] Journal Parasite and Vectors. Tersedia di: < https:// parasitesandvectors.biomedcentral. com/track/pdf/10.1186/1756-3305$4-242$ ? site $=$ parasitesandvectors . biomedcentral.com $>$ [diakses pada tanggal 7 Agustus 2017].

Aisyah, S.T., 2010. Pengaruh Pola Asuh Orang Tua Terhadap Tingkat Agresifitas Anak. Jurnal MEDTEK, Vol. 2, No. 1. Tersedia di: $<$ ft-unm.net/medtek/ Jurnal_Medtek_Vol.2_No.1_April_2010/ ARTIKEL\%20IBU\%20ICHA\%20PKK. pdf $>$ [diakses pada tanggal $27 \mathrm{Mei}$ 2017].

Alemu, A., Atnafu, A., Addis, Z., Shiferaw, Y., Teklu, T., Mathewos, Z., Birhan, W., Gebretsadik, S., dan Gelaw, B., 2011. Soil Transmitted Helminths and Schistosoma Mansoni Infections Among School Children in Zarima Town, Nortwest Ethiopia. [e-journal] BMC Infectious Disease DOI: 10.1186/1471-2334-11189. Tersedia di: < https://www.ncbi. nlm.nih.gov/pubmed/21740589> [diakses pada tanggal 7 Agustus 2017].

Al-Fanjari, A.S., 1999. Nilai Kesehatan Dalam Syariat Islam. Jakarta: Bumi Aksara. 
Awasthi, S., Verma, T., Kotecha, P.V., Venkatesh, V., Joshi, V., dan Roy, S., 2008. Prevalence and Risk Factors Associated with Worm Infestation in Pre-School Children (6-23 Months) in Selected Blocks of Uttar Pradesh and Jharkhand, India. [e-journal] Indian J Med Sci, Vol. 62. No. 12. Tersedia di: < http://www. bioline.org.br/pdf?ms08088> [diakses pada tanggal 7 Agustus 2017].

BPS Jatim., 2010. Provinsi Jawa Timur Dalam Angka 2009, Surabaya.

Bigner, J.J., 1979. Parent Child Realtion. An Introduction to Parenting. New York: Macmillan Publishing Co., Inc.

Dasilva, E.B.X., Sri, H., dan Sri, R., 2012. Association Between Rearing Pattern of Parent and Personal Hygiene Status of Children with Slight and Medium Mental Retardation at SLB Negeri II Yogyakarta. E-Journal Respati, 1-14. Tersedia di: $<$ https://www.scrib.com/doc/171090130/ Jurnal-Elisabeth-BX-Dasilva $>$ [diakses pada tanggal pada 22 Mei 2017].

Depkes RI., 2006. Profil Kesehatan Indonesia 2005. Jakarta: Pusat data dan Informasi.

Depkes RI., 2009. Profil Kesehatan Indonesia 2008. Jakarta: Pusat Data dan Informasi.

Direktorat Kesejahteraan Anak, Keluarga dan Lanjut Usia., 2001. Intervensi Psikososial. Jakarta: Departemen Sosial RI.

Gandahusada, S., Ilahude, D.H., dan Pribadi, W., 2000. Parasitologi Kedokteran. Jakarta: Fakultas Kedokteran Universitas Indonesia.

Herlina., 2013. Hubungan Pola Asuh Keluarga dengan Kemandirian Perawatan Diri Anak Usia Sekolah Di Kelurahan Cisalak Pasar Kecamatan Cimanggis Kota Depok. Thesis. Universitas Indonesia.

Hidayat, A.A., 2008. Pengantar Ilmu Kesehatan Anak. Jakarta: Salemba Medika.

Idris, Z., dan Jamal, L., 1992. Pengantar Pendidikan 2. Jakarta: PT. Grasindo.

Isro'in, L., dan Andarmoyo, S., 2012. Personal Hygiene. Yogyakarta: Graha Ilmu.
Joshi, S., dan Acharya, N., 2013. Home Environment and Achievement Motivation of Adolescents. Social Science Internasional. [e-journal] Tersedia di: < https://search.proquest.com/openview/ $3 \mathrm{cda} 70723 \mathrm{fa} 9 \mathrm{bdb} 4 \mathrm{c} 084 \mathrm{fd} 413 \mathrm{c} 4 \mathrm{f} 0 \mathrm{dd} 4 /$ 1 ? pq-origsite $=$ gscholar $\& \mathrm{cbl}=506333>$ [diakses pada tanggal 7 Agustus 2017].

Kemenkes RI. 2009. Undang-undang Nomor 36 Tahun 2009 tentang Kesehatan. Jakarta: Kesehatan RI.

Kemenkes RI., 2013. Riset Kesehatan Dasar. Jakarta: Badan Penelitian dan Pengembangan Kesehatan.

Kemensos RI, Save the Children, UNICEF., 2007. Someone That Matters: The Quality Of Care In Childcare Institutions In Indonesia. Save The Children UK, The Ministry of Social Affairs dan UNICEF. Jakarta.

Kepmensos RI., 2010. Keputusan Menteri Sosial Republik Indonesia No. 15 Tahun 2010 tentang Panduan Umum Program Kesejahteraan Sosial Anak. Jakarta: Kemensos RI.

Lintang., 2014. Hubungan Pola Asuh Orang Tua Dengan Personal Hygiene Pada Anak Tuna Grahita Di SLBN Ungaran. Skripsi. AKBID NWU KTI. Tersedia di: https://digilib.uns.ac.id/dokumen/ download/190480/MTkwNDgw [diakses pada tanggal 26 Mei 2017].

Mardliyah, U., Yugistyowati, A., dan Aprilia, V., 2013. Pola Asuh Orang Tua Sebagai Faktor Penentu Kualitas Pemenuhan Kebutuhan Dasar Personal Hygiene Anak Asuh Usia 6-12 Tahun. Jurnal Ners dan Kebidanan Indonesia. Vol. 2, No. 2, tahun 2014, 86-92. Tersedia di < ejournal. almaata.ac.id/index.php/JNKI/article/ download/32/31> [diakses pada tanggal 25 Mei 2017].

Mussen, P.H., 1994. Perkembangan dan Kepribadian Anak. Jakarta: Arcan.

Naim, S., 2017. Pola Asuh Orang Tua Terhadap Status Personal Hygiene pada Anak Prasekolah di RA Al-Hidayah Jombang. Jurnal Humaniora, Vol. 14, No. 1, hlm 1-7. 
Notoatmodjo, S., 2003. Ilmu Kesehatan Masyarakat. Jakarta: Rineka Cipta.

Potter, P.A., dan Perry, A.G., 2006. Buku Ajar Fundamental Keperawatan: Konsep, Proses dan Praktik. Jakarta: EGC.

Pusat Data dan Informasi., 2013. Profil Kesehatan Indonesia 2012. Jakarta: Kementerian Kesehatan RI.

Raffaelli, M., dan Koller, S. H., 2005. Future Expectations of Brasilian Street Youth. Journal of Adolescence, [e-jornal] 28(2), 249-262. Tersedia di: https://ncbi.nlm. nih.gov/pubmed/?term=Future+Expectati ons + of + Brasilian + Street + Youth [diakses tanggal 3 Desember 2016]

Rahmadani., 2013. Latar Belakang Penyebab Anak-Anak Bekerja Di Jalanan (Studi: 8 Orang Anak Jalanan di Kota Tanjung Pinang). Skripsi. Universitas Maritim Raja Ali Haji Tanjungpinang.

Rahman, N., 2014. Faktor-Faktor yang Berhubungan dengan Perilaku Personal Hygiene pada Saat Menstruasi di SMP Muhammadiyah 5 Yogyakarta Tahun 2014. Skripsi. Sekolah Tinggi Ilmu Kesehatan 'Aisyiyah Yogyakarta. Tersedia di http:/opac.unisayogya.ac.id/1116/1/ Naskah\%20Publikasi.pdf [diakses pada 5 Juni 2017].

Rosyidah, A.N., 2014. Hubungan Perilaku Cuci Tangan Terhadap Kejadian Diare Pada Siswa Di Sekolah Dasar Negeri Ciputat 02. Skripsi. Universitas Islam Negeri Syarif Hidayatullah.

Rothbart, M.K., dan Bates, J.E., 1998. Temperament. Handbook of Child Psychology.

Sandriana., Ibnu, I.F., dan Rachman, W. A., 2014. Perilaku Personal Hygiene Genetalia Santriwati Di Pesantren Ummul Mukminin Makassar Sulawesi Selatan.
Tersedia di: < http://repository.unhas. ac.id/bitstream/handle/123456789/13089/ sandriana.pdf? sequence $=1>$ [diakses pada 6 Juli 2017].

Sanson, A.V., dan Rothbart, M.K., 1995. Child Temperament and Parenting.

Santrock, J.W., 2004. Child Development. Wisconsin: Wm. C. Brown Communication, Inc.

Siswanto, H., 2010. Pendidikan Anak Usia Dini. Yogyakarta: Pustaka Rihama.

Soetjiningsih., 1995. Tumbuh kembang Anak. Jakarta: EGC.

Tridhonanto, A., dan Agency, B., 2014. Mengembangkan Pola Asuh Demokratis. Jakarta: PT. Elex Media Komputindo.

Turner, E.A., Chandler, M., \&dan Heffer, R.W., 2009. The Influence of Parenting Styles, Achievement Motivation, and Self-Efficacy on Academic Performance in Collage Students. Journal of Collage Student Development. Tersedia di: $<$ https://numerons.files.wordpress. com/2012/04/13the-influence-ofparenting-styles-and-achievementmotivation.pdf $>$ [diakses pada tanggal 7 Agustus 2017].

Wachs, T., 2000. Neccessary But Not Sufficient: The Respective Roles Of Single And Multiple Influences On Individual Development. American Psychological Association.

Walgito, B., 2004. Pengantar Psikologi Umum. Andi: Yogyakarta.

Wong, D.L., Eaton, M. H., Wilson, D., Winkelstein, M.L., dan Schwartz, P., 2008. Buku Ajar Keperawatan Pediatrik. Jakarta: EGC.

WHO. 1948. Definition of Health. http:// www.who.int/about/definition/en/print. html [Sitasi: 5 Juli 2017]. 